CLINICAL STUDY

\title{
Combined evaluation of resting IGF 1, N-terminal propeptide of type III procollagen and C-terminal cross-linked telopeptide of type I collagen levels might be useful for detecting inappropriate GH administration in female athletes
}

\author{
Luigi Di Luigi, Antonello E Rigamonti ${ }^{1}$, Fiorenza Agosti ${ }^{2}$, Monica Mencarelli $^{3}$, Paolo Sgrò, Nicoletta Marazzi ${ }^{2}$, \\ Silvano G Cella ${ }^{1}$, Eugenio E Müller ${ }^{1}$ and Alessandro Sartorio ${ }^{2,4}$ \\ Unità di Endocrinologia, Dipartimento di Scienze della Salute, Università di Roma 'Foro Italico', Piazza Lauro de Bosis 15, O0194 Roma, Italy, \\ ${ }^{1}$ Dipartimento di Farmacologia Medica, Università di Milano, Via Vanvitelli 32, 20129 Milano, Italy, ${ }^{2}$ Istituto Auxologico Italiano, Laboratorio \\ Sperimentale Ricerche Auxo-Endocrinologiche (LSRAE), ${ }^{3}$ Laboratorio di Biologia Molecolare and ${ }^{4}$ Divisione Malattie Metaboliche III, IRCCS, 20145 \\ Milano e 28044 Piancavallo (VB), Italy \\ (Correspondence should be addressed to L Di Luigi; Email: luigi.diluigi@iusm.it)
}

\begin{abstract}
Objective: To detect exogenous recombinant human $\mathrm{GH}$ (rhGH) abuse in female athletes. Design: GH-dependent markers were assayed in serum of 100 female athletes (control group) and in a subgroup of nine female subjects treated with $\mathrm{rhGH}(0.09 \mathrm{IU} / \mathrm{kg}$ body weight, 6 days/week for 3 weeks).

Methods: Cut-off values (mean +2 s.D.) for IGF1, N-terminal propeptide of type III procollagen (PIIINP) and C-terminal telopeptide of type I collagen (ICTP) were calculated and arbitrary scores (1.5 or 2.0) were assigned to abnormal markers. By using the sum of individual marker scores, positive $(\geq 3)$ or negative $(<3)$ scores were obtained.

Results: None of the control group obtained a positive score $(\geq 3)$. Abnormal IGF1, PIIINP and ICTP levels were found in $61.4,54.5$ and $11.4 \%$ samples of the treated group. Overall, positive cases were present in $43.2 \%$ blood samples drawn in subjects treated with rhGH and in $26 \%$ of samples after rhGH withdrawal. The sensitivity of the detection approach was $66.6 \%$ at the end of 3-week rhGH treatment and $11.1 \%$ at the 15 th day of rhGH withdrawal, while the specificity was $100 \%$.

Conclusion: Detection test for rhGH administration appears less sensitive in female $(66.6 \%)$ than in male athletes (previous observation, $100 \%$ after 3 weeks of comparable rhGH dose), but shows a similar specificity (98.5-100\%). Since athletes supposedly use very high doses and long-term administration of rhGH for doping purposes, it is foreseen that the here-in detection test would in future increase its strength.
\end{abstract}

European Journal of Endocrinology 160 753-758

\section{Introduction}

There is anecdotal evidence that recombinant human $\mathrm{GH}(\mathrm{rhGH})$ is widely abused in sport, either alone or in combination with androgenic anabolic steroids (1). To date, however, there is a lack of evidence that rhGH actually improves performance in sound athletes, although beneficial effects have been demonstrated in adults with GH deficiency (2).

Development of a valid anti-doping test for $\mathrm{GH}$ has been challenging because $22 \mathrm{kDa}$ rhGH used in doping is analytically indistinguishable from endogenous $\mathrm{GH}$ and there are wide-physiological fluctuations in circulating concentrations of endogenous $\mathrm{GH}$ (3).

One approach to rhGH detection in sport is based on measurement of different circulating $\mathrm{GH}$ isoforms using immunoassays that differentiate between $22 \mathrm{kDa}$ and other GH isoforms. Administration of $22 \mathrm{kDa}$ GH results in a change in its abundance relative to other endogenous pituitary GH isoforms. However, this differential isoform method has a limited utility because of the short window of opportunity of detection of circulating $\mathrm{GH}(4,5)$.

The second present approach to a GH doping test is based on the physiological effects of rhGH that result in increased circulating concentrations of proteins with a longer half-life and more stable serum concentrations than GH, such as insulin-like growth factor I (GF1) and bone and collagen peptides. These include the marker of bone formation, N-terminal propeptide of type I procollagen, the marker of bone resorption, C-terminal telopeptide of type I collagen (ICTP) and the marker of connective tissue synthesis N-terminal propeptide of type III procollagen (PIIINP) (6-8). 
Combination of more than one marker through a multistep algorithm (9) or mathematical equation (10-12) has been reported to result in a more suitable integrated evaluation of GH-IGF1 function and in a highly predictive anti-doping test for $\mathrm{GH}$ abuse.

Along this line are preliminary results by Sartorio et al. (9), who evaluated the usefulness of combined measurements of IGF1, PIIINP and ICTP in detecting exogenous rhGH administration in male subjects (0.09 IU/kg body weight, 6 days/week for 3 weeks), after having calculated cut-off values (mean +2 s.D.) for these markers in a control group (not-treated athletes). The sensitivities of the detection approach ranged between 50 and $100 \%$ (at the 1st, 2nd and 3rd week) and specificity was $98.5 \%$.

Reportedly, in addition to age, gender is a major determinant of variability for IGF1 and the bone and collagen markers (13). This is related to women's resistance to the effect of $\mathrm{GH}$ on hepatic metabolism and bone and collagen turnover, as shown by the higher baseline levels of bone formation markers and by the significantly greater response to low doses of rhGH in IGF1, PIIINP and ICTP levels in male than female athletes (7).

This gender-related difference in the response to rhGH might make the detection of $\mathrm{GH}$ abuse in women potentially more difficult.

Therefore, the aim of the present study was to ascertain whether the combined determination of IGF1, PIIINP and ICTP could be useful in detecting exogenous rhGH administration also in female athletes. To make the comparison with the results of our previous study (9) easier, the same protocol used in male athletes was here-in followed, with the distinction of monitoring biological markers also after rhGH treatment withdrawal.

\section{Materials and methods}

\section{Subjects}

One hundred Caucasian female athletes from different individual or team sports, competing at a national level, (control group; mean age \pm s.D.: $22.2 \pm 4.6$ years; body mass index (BMI): $20.6 \pm 1.6 \mathrm{~kg} / \mathrm{m}^{2}$ ) volunteered to participate in this investigation. They had regularly trained (at least $2-3 \mathrm{~h} /$ day for $4-5$ days/week) during the 2-3 years preceding the present study and they had not taken medications, drugs or doping agents that might have influenced the experimental evaluation during the year prior to blood collections. A full physical examination and a preliminary screening assessment were devised to detect risk factors that might contraindicate participation in the study. The risks and benefits of the study were thoroughly explained to all subjects, and written informed consent was subsequently obtained. Approval was also obtained by the ethical committees of the Italian Institute for Auxology, Milan and of the University 'Sapienza', Rome, Italy.

After the basal evaluation, a small group of female athletes (treated group; $n=9$; age: $24.2 \pm 3.5$ years; BMI: $20.8 \pm 1.5 \mathrm{~kg} / \mathrm{m}^{2}$ ) involved in non-competitive sport activities (not including anti-doping controls), additionally volunteered to be treated with rhGH (Humatrope, Eli Lilly) at a dose of $0.09 \mathrm{IU} / \mathrm{kg}$ body weight, administered subcutaneously 6 days/week for 3 weeks. To be assured of compliance each daily rhGH dose was administered by a physician. This approach could be questionable as it was obviously not randomized and blinded, but was, however, recommended by our ethical committees.

\section{Blood collection and biochemical analyses}

Control group athletes were sampled in the morning $(1000-1200 \mathrm{~h})$ or in the afternoon (1600-1900 h) before a typical training session, according to their usual training schedule. Before blood sampling, subjects were asked to fast for at least $3 \mathrm{~h}$ and refrain from physical activity and ingestion of alcohol or caffeine. Basal blood samples were drawn after the athletes stood quietly for at least $30 \mathrm{~min}$ in a semirecumbent position.

In the treated group, blood collections were performed in the morning before the daily rhGH administration on the following days: 1 (i.e. baseline), 3, 4, 8, 15 and 20. A further set of blood samples was drawn after rhGH withdrawal at the following days: 1, 2, 4, 8, 15,30 and 60. Blood samples were placed on ice until centrifugation and serum separation. Serum samples were frozen at $-40{ }^{\circ} \mathrm{C}$ until analyzed.

The circadian variability of IGF1, ICTP and PIIINP is limited and the different times of blood collection (morning versus afternoon) did not affect the results.

Serum GH and IGF1 levels were determined by using commercial kits for enzyme-labelled chemiluminescent immunometric assay (Immulite 2000, DPC, Los Angeles, CA, USA and Mediagnost $\mathrm{GmbH}$, Tuebingen, Germany respectively). Values of sensitivity were

Table 1 Parameter scores (means +2 s.D.) as a function of age group. Values determined in 100 female athletes.

\begin{tabular}{lccl}
\hline & $\begin{array}{c}\text { Age group } \\
\text { (years) }\end{array}$ & Cut-off value & Points \\
\hline IGF1 $(\mathrm{nmol} / \mathrm{l})$ & $\leq 30$ & $\geq 54.0$ & 2 \\
& $\leq 30$ & $<54.0$ & 0 \\
& $>30$ & $\geq 45.8$ & 2 \\
& $>30$ & $<45.8$ & 0 \\
PIIINP $(\mu \mathrm{g} / \mathrm{l})$ & $\leq 20$ & $\geq 7.3$ & 1.5 \\
& $\leq 20$ & $<7.3$ & 0 \\
& $>20$ & $\geq 5.6$ & 1.5 \\
& $>20$ & $<5.6$ & 0 \\
$\operatorname{ICTP}(\mu \mathrm{g} / \mathrm{l})$ & $\leq 20$ & $\geq 8.3$ & 1.5 \\
& $\leq 20$ & $<8.3$ & 0 \\
& $>20$ & $\geq 6.7$ & 1.5 \\
& $>20$ & $<6.7$ & 0 \\
\hline
\end{tabular}


$0.01 \mu \mathrm{g} / \mathrm{l}$ for $\mathrm{GH}$ and $0.01 \mathrm{nmol} / \mathrm{l}$ for IGF1. Intra- and interassay coefficients of variation $(\mathrm{CV})$ were 2.5 and $6 \%$ for $\mathrm{GH}$ and 3.5 and $7 \%$ for IGF1 respectively. ICTP and PIIINP levels were determined using commercial kits for RIA (Orion Diagnostica Oy, Espoo, Finland). Intra- and interassay CV were 5.2 and $5.7 \%$ for ICTP and 4.3 and $5.3 \%$ for PIIINP; the sensitivity was $0.5 \mu \mathrm{g} / \mathrm{l}$ for ICTP and $0.2 \mu \mathrm{g} / \mathrm{l}$ for PIIINP.

All the samples were run in the same session to avoid any changes in interassay variability.

\section{Single marker and total scores}

Cut-off values for abnormal IGF1, PIIINP and ICTP $(+2$ S.D. from the means) were calculated using the data of the entire subject group of controls. By analogy with the approach used in a previous study by our group in male athletes (9), we arbitrarily assigned 2 (IGF1) or 1.5 (PIIINP and ICTP) scores to abnormal values in the respective age groups, as reported in Table 1 . Total scores (i.e. the sum of the three marker scores) lower than three were arbitrarily considered negative for rhGH intake, while scores equal to or higher than three were considered positive.

\section{Statistical and data analyses}

Ordinary statistical methods were used to calculate means and S.D. Sensitivity was calculated ((abnormal cases/total number of samples) $\times 100$ ) in the treated group at the different times of blood sampling; specificity was calculated ((normal cases/total number of subjects $) \times 100)$ in the control group.

A test of normality and an equal variance test were performed for all markers before the use of parametric tests. For the treated group, a repeated measures ANOVA was used to assess the effect of the treatment between the different times of blood sampling on IGF1, PIIINP and ICTP levels. When significant treatment effects occurred, Tukey post hoc analyses were used to test differences among means. The level of significance was established at $P<0.05$. The statistical software package used was SigmaStat version 3.0.1.

\section{Results}

Abnormal IGF1, PIIINP and ICTP levels were present in $4 / 100(4 \%), 3 / 100(3 \%)$ and $0 / 100(0 \%)$ cases of the not-treated (control) group respectively, but no athlete displayed a positive total score $(\geq 3)$ in this group. $\mathrm{GH}$ levels in the not-treated group averaged $5.7 \pm 4.8 \mu \mathrm{g} / \mathrm{l}$.

As reported in Table 2, abnormal levels of IGF1, PIIINP and ICTP were found in 27/44 (61.4\%), 24/44 (54.5\%) and 5/44 (11.4\%) blood samples of rhGHtreated female subjects respectively.

The profile of the three markers during the entire periods of rhGH administration and withdrawal is
Table 2 Serum insulin-like growth factor I (IGF1), N-terminal propeptide of type III procollagen (PIIINP), C-terminal telopeptide of type I collagen (ICTP) concentrations and total scores for recombinant human $\mathrm{GH}(\mathrm{rhGH})$-treated female athletes during the 3-week treatment $(0.09 \mathrm{lU} / \mathrm{kg}$ body weight, 6 days/week).

\begin{tabular}{|c|c|c|c|c|c|}
\hline Cases & $\begin{array}{c}\text { Treatment } \\
\text { day }\end{array}$ & $\begin{array}{c}\text { IGF1 } \\
(\mathrm{nmol} / \mathrm{I})\end{array}$ & $\begin{array}{c}\text { PIIINP } \\
(\mu \mathrm{g} / \mathrm{l})\end{array}$ & $\begin{array}{l}\text { ICTP } \\
(\mu \mathrm{g} / \mathrm{I})\end{array}$ & $\begin{array}{l}\text { Total } \\
\text { score }\end{array}$ \\
\hline 1 & $\begin{array}{r}1 \\
3 \\
4 \\
8 \\
15 \\
20\end{array}$ & $\begin{array}{l}26.5 \\
36.3 \\
37.6 \\
33.9 \\
31.5 \\
84.8^{a}\end{array}$ & $\begin{array}{l}3.5 \\
3.6 \\
3.5 \\
5.1 \\
3.6 \\
5.2\end{array}$ & $\begin{array}{l}3.4 \\
3.9 \\
4.3 \\
5.7 \\
4.5 \\
4.7\end{array}$ & $\begin{array}{l}0 \\
0 \\
0 \\
0 \\
0 \\
2\end{array}$ \\
\hline 2 & $\begin{array}{r}1 \\
3 \\
4 \\
8 \\
15 \\
20\end{array}$ & $\begin{array}{l}44.6 \\
65.9^{a} \\
49.6 \\
37.2 \\
48.5 \\
92.9^{a}\end{array}$ & $\begin{array}{l}4.9 \\
5.7^{\mathrm{a}} \\
5.5 \\
7.2^{\mathrm{a}} \\
5.9^{\mathrm{a}} \\
7.1^{\mathrm{a}}\end{array}$ & $\begin{array}{l}4.5 \\
5.1 \\
5.9 \\
6.4 \\
4.2 \\
5.6\end{array}$ & $\begin{array}{l}0 \\
3.5^{b} \\
0 \\
1.5 \\
1.5 \\
3.5^{b}\end{array}$ \\
\hline 3 & $\begin{array}{r}1 \\
3 \\
4 \\
8 \\
15 \\
20\end{array}$ & $\begin{array}{r}72.1^{\mathrm{a}} \\
71.9^{\mathrm{a}} \\
75.4^{\mathrm{a}} \\
66.1^{\mathrm{a}} \\
69.9^{\mathrm{a}} \\
121.2^{\mathrm{a}}\end{array}$ & $\begin{array}{l}3.3 \\
2.6 \\
7.2^{a} \\
5.0 \\
7.0^{a} \\
7.3^{a}\end{array}$ & $\begin{array}{l}3.1 \\
1.9 \\
2.7 \\
3.4 \\
5.1 \\
5.6\end{array}$ & $\begin{array}{l}2 \\
2 \\
3.5^{b} \\
2 \\
3.5^{b} \\
3.5^{b}\end{array}$ \\
\hline 4 & $\begin{array}{r}1 \\
3 \\
4 \\
8 \\
15 \\
20\end{array}$ & $\begin{array}{l}51.7 \\
81.2^{a} \\
71.2^{a} \\
59.7^{a} \\
50.5 \\
86.7^{a}\end{array}$ & $\begin{array}{l}5.0 \\
6.0^{\mathrm{a}} \\
6.4^{\mathrm{a}} \\
7.2^{\mathrm{a}} \\
5.8^{\mathrm{a}} \\
6.7^{\mathrm{a}}\end{array}$ & $\begin{array}{l}4.6 \\
5.6 \\
3.5 \\
6.8^{a} \\
6.7^{a} \\
6.2\end{array}$ & $\begin{array}{l}0 \\
3.5^{\mathrm{b}} \\
3.5^{\mathrm{b}} \\
5^{\mathrm{b}} \\
3^{\mathrm{b}} \\
3.5^{\mathrm{b}}\end{array}$ \\
\hline 5 & $\begin{array}{r}1 \\
3 \\
4 \\
8 \\
15 \\
20\end{array}$ & $\begin{array}{l}55.0^{\mathrm{a}} \\
54.1^{\mathrm{a}} \\
53.2 \\
44.3 \\
39.4 \\
59.0^{\mathrm{a}}\end{array}$ & $\begin{array}{l}5.8^{\mathrm{a}} \\
6.9^{\mathrm{a}} \\
7.3^{\mathrm{a}} \\
6.2^{\mathrm{a}} \\
5.9^{\mathrm{a}} \\
9.7^{\mathrm{a}}\end{array}$ & $\begin{array}{l}5.2 \\
5.2 \\
4.9 \\
4.6 \\
6.1 \\
5.4\end{array}$ & $\begin{array}{l}3.5^{\mathrm{b}, \mathrm{c}} \\
3.5^{\mathrm{b}} \\
1.5^{-5} \\
1.5^{-} \\
1.5^{\mathrm{b}} \\
3.5^{\mathrm{b}}\end{array}$ \\
\hline 6 & $\begin{array}{r}1 \\
3 \\
4 \\
8 \\
15 \\
20\end{array}$ & $\begin{array}{l}45.7 \\
67.7^{a} \\
63.6^{a} \\
44.6 \\
94.4^{a} \\
97.4^{a}\end{array}$ & $\begin{array}{l}4.7 \\
5.3 \\
5.0^{\mathrm{a}} \\
8.5^{\mathrm{a}} \\
9.9^{\mathrm{a}} \\
9.4^{\mathrm{a}}\end{array}$ & $\begin{array}{l}5.3 \\
5.7 \\
6.4 \\
7.7^{\mathrm{a}} \\
8.5^{\mathrm{a}} \\
8.7^{\mathrm{a}}\end{array}$ & $\begin{array}{l}0 \\
2 \\
3.5^{b} \\
3^{b} \\
5^{b} \\
5^{b}\end{array}$ \\
\hline 7 & $\begin{array}{r}1 \\
3 \\
4 \\
8 \\
15 \\
20\end{array}$ & $\begin{array}{r}46.2 \\
69.7^{\mathrm{a}} \\
75.3^{\mathrm{a}} \\
69.7^{\mathrm{a}} \\
121.9^{\mathrm{a}} \\
188.8^{\mathrm{a}}\end{array}$ & $\begin{array}{l}5.0 \\
5.7^{\mathrm{a}} \\
4.7 \\
5.1 \\
5.6^{\mathrm{a}} \\
5.8^{\mathrm{a}}\end{array}$ & $\begin{array}{l}4.3 \\
4.1 \\
4.0 \\
6.1 \\
6.1 \\
5.7\end{array}$ & $\begin{array}{l}0 \\
3.5^{\mathrm{b}} \\
2 \\
2 \\
3.5^{\mathrm{b}} \\
3.5^{\mathrm{b}}\end{array}$ \\
\hline 8 & $\begin{array}{r}1 \\
3 \\
4 \\
8 \\
15 \\
20\end{array}$ & $\begin{array}{l}37.0 \\
47.1^{a} \\
48.1^{a} \\
44.6 \\
59.4^{a} \\
89.8^{a}\end{array}$ & $\begin{array}{l}2.5 \\
2.8 \\
3.2 \\
2.6 \\
2.5 \\
2.8\end{array}$ & $\begin{array}{l}3.6 \\
3.7 \\
3.8 \\
3.3 \\
4.1 \\
4.4\end{array}$ & $\begin{array}{l}0 \\
2 \\
2 \\
0 \\
2 \\
2\end{array}$ \\
\hline 9 & $\begin{array}{r}1 \\
3 \\
4 \\
8 \\
15 \\
20\end{array}$ & $\begin{array}{c}31.7 \\
39.8 \\
45.5 \\
34.2 \\
/ \\
43.3\end{array}$ & $\begin{array}{l}2.4 \\
2.8 \\
2.7 \\
3.5 \\
/ \\
3.3\end{array}$ & $\begin{array}{l}2.3 \\
4.5 \\
4.0 \\
2.7 \\
/ \\
3.2\end{array}$ & $\begin{array}{l}0 \\
0 \\
0 \\
0 \\
1 \\
0\end{array}$ \\
\hline
\end{tabular}

${ }^{\mathrm{a} A b n o r m a l ~ v a l u e s . ~}$

${ }^{b}$ Positive total score (in bold).

${ }^{\mathrm{c}}$ False positive, since blood samples were drawn before rhGH administration. 

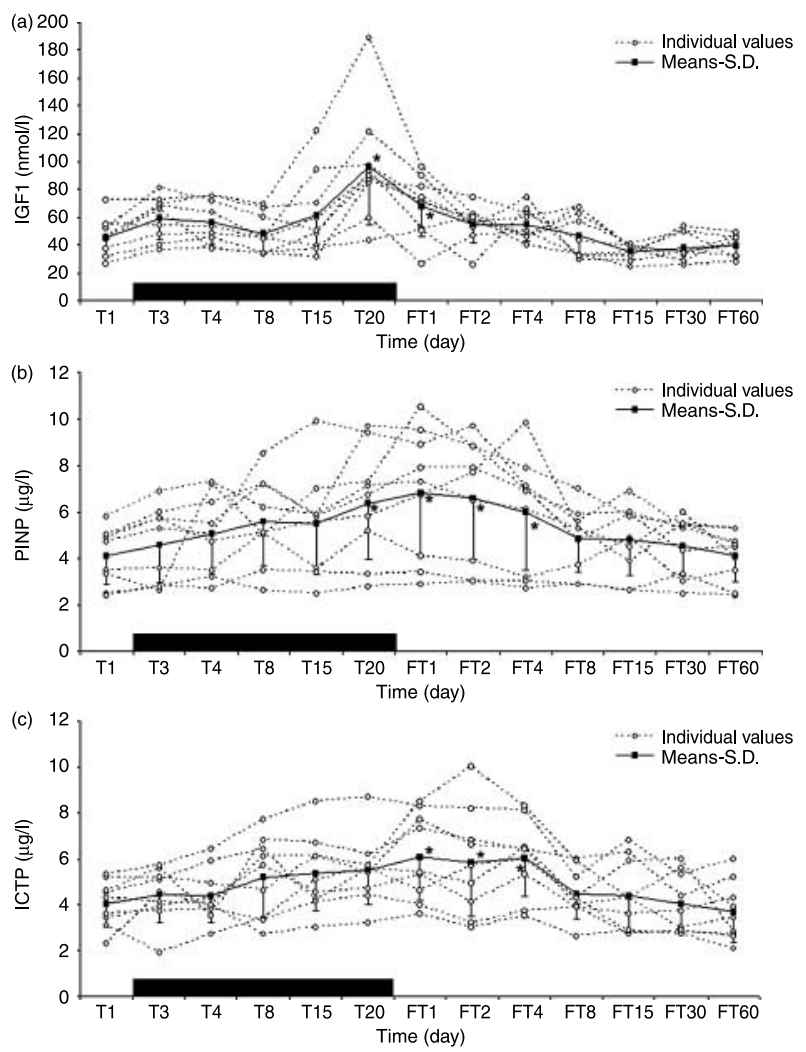

Figure 1 Serum IGF1 (a), PIIINP (b) and ICTP (c) levels in female athletes $(n=9)$ immediately before (T1, baseline values), during (T3, T4, T8, T15 and T20 days) and after (FT1, FT2, FT4, FT8, FT15, FT30 and FT60 days) the administration of recombinant human GH (rhGH: $0.09 \mathrm{IU} / \mathrm{kg}$ body weight, 6 days/week for 3 weeks). All values are expressed as the means-S.D. ${ }^{*} P<0.05$, compared with baseline (repeated measures ANOVA followed by Tukey post hoc). The black box indicates the 3-week rhGH treatment. T, treatment; FT, free from treatment.

reported in Fig. 1. Levels of all markers progressively increased in the first 3-week treatment and then decreased until equalling baseline levels after 8 (IGF1), 30 (PIIINP) and 60 (ICTP) days. Scrutiny of the three markers after rhGH withdrawal provides evidence that, although with a wide inter-individual variability, IGF1 levels remained elevated for 4-8 days after rhGH withdrawal (in seven athletes, cases 1, 3, 4, 6-9), abnormal PIIINP levels up to 15 days (in four athletes, cases 3-6) and up to 30 days (in one athlete, case 2). ICTP levels, which increased slightly during rhGH administration, remained abnormal for up to 4 days in only two athletes (cases 6 and 7).

Collectively, the specificity of the detection approach proposed here was 100\% (0 false positives among not-treated athletes), whereas the values of sensitivity were 44.4 (4/9), 33.3 (3/9), 22.2 (2/9), 50.0 (4/8) and $66.6 \%(6 / 9)$ among blood samples drawn at the 3rd, 4 th, 8th, 15th and 20th day of rhGH treatment, respectively (Table 2). It has to be noted that athlete case 5 was a false positive.
Interestingly, cases of positive total score also were present after 1, 2 and 4 days of rhGH withdrawal. The values of sensitivity were $62.5(5 / 8), 33.3(3 / 9)$ and $37.5 \%(3 / 8)$ at the 1 st, 2 nd and 4 th, $11.1 \%(1 / 9)$ at the 8 th and 15 th and $0 \%(0 / 9$ and $0 / 7)$ at 30th and 60th days after withdrawal of rhGH treatment respectively (Table 3).

\section{Discussion}

In a previous study, IGF1, PIIINP and ICTP concentrations were reported to be of potential interest for assessing rhGH abuse in male athletes (9). Precisely, assignment of a distinct score to each of these $\mathrm{GH}$-dependent markers resulted in only one false positive case in a group of 66 male athletes, freed from $\mathrm{GH}$ use. On the other hand, 12/18 positive samples were present in male subjects treated with rhGH (0.09 IU/kg, 6 days/week for 3 weeks; 66.7\%), the occurrence of positive scores being $6 / 6$ at the 3 rd week of treatment and 3/6 at the 1st and 2nd weeks. Hence, based on a cut-off value for total score of $\geq 3$, the detection approach proposed in that study had a sensitivity value of $50 \%$ at the 1 st and 2 nd weeks of rhGH treatment and of $100 \%$ at the end of the 3rd week and a specificity of $98.5 \%$.

In the present study, we have investigated whether the same markers might be applied in detecting rhGH administration in female athletes, too.

The combined determinations of IGF1, PIIINP and ICTP levels in 100 female athletes freed from GH use, and the subsequent assignment of a specific score to each of these three markers was endowed with a 100\% specificity. In fact, increased IGF1, PIIINP and ICTP levels were found respectively, in only 4/100 (4\%), $3 / 100(3 \%)$ and $0 / 100(0 \%)$ control athletes, with none having a total score of $\geq 3$.

When considering female subjects treated with rhGH, abnormal IGF1, PIIINP and ICTP levels were found in $27 / 44(61.4 \%), 24 / 44(54.5 \%)$ and 5/44 (11.4\%) blood samples respectively. Importantly, a greater percentage of increased IGF1, PIIINP and ICTP levels was found at the 15 th and 20th days of rhGH treatment.

In contrast with the results obtained in male subjects (see above), these findings imply that 3 weeks of rhGH treatment at the (low) dose used here failed to engender sustained and increased levels of the GH-dependent markers in most of the female individuals.

These apparently negative findings have to be related to the reduced sensitivity to rhGH of women and are in agreement with previous reports that GH deficient and also healthy men are more responsive to rhGH administration than women $(7,14)$. In this study, resistance to rhGH was apparently more prominent when the bone marker of resorption ICTP is considered (14). 
Table 3 Serum insulin-like growth factor I (IGF1), N-terminal propeptide of type III procollagen (PIIINP), C-terminal telopeptide of type I collagen (ICTP) concentrations and total scores for recombinant human $\mathrm{GH}$ (rhGH)-treated female athletes after treatment withdrawal.

\begin{tabular}{|c|c|c|c|c|c|}
\hline Cases & $\begin{array}{l}\text { Withdrawal } \\
\text { day }\end{array}$ & $\begin{array}{l}\text { IGF1 } \\
(\mathrm{nmol} / \mathrm{I})\end{array}$ & $\begin{array}{c}\text { PIIINP } \\
(\mu \mathrm{g} / \mathrm{l})\end{array}$ & $\begin{array}{l}\text { ICTP } \\
(\mu \mathrm{g} / \mathrm{l})\end{array}$ & $\begin{array}{l}\text { Total } \\
\text { score }\end{array}$ \\
\hline \multirow[t]{7}{*}{1} & 1 & $81.7^{\mathrm{a}}$ & 4.1 & 5.3 & 2 \\
\hline & 2 & $74.7^{\mathrm{a}}$ & 3.9 & 4.1 & 2 \\
\hline & 4 & $62.6^{a}$ & 3.2 & 5.3 & 2 \\
\hline & 8 & 42.9 & 3.7 & 3.9 & 0 \\
\hline & 15 & 38.8 & 4.9 & 3.6 & 0 \\
\hline & 30 & 35.1 & 3.0 & 3.7 & 0 \\
\hline & 60 & 40.0 & 3.5 & 4.3 & 0 \\
\hline \multirow[t]{7}{*}{2} & 1 & 51.5 & $7.3^{\mathrm{a}}$ & 4.6 & 1.5 \\
\hline & 2 & $59.1^{\mathrm{a}}$ & 6.5 & 5.7 & 2 \\
\hline & 4 & 40.5 & $6.1^{\mathrm{a}}$ & 6.0 & 1.5 \\
\hline & 8 & 32.5 & 5.3 & 4.3 & 0 \\
\hline & 15 & 34.6 & 4.5 & 5.9 & 0 \\
\hline & 30 & 49.7 & $6.0^{\mathrm{a}}$ & 6.0 & 1.5 \\
\hline & 60 & 30.3 & 4.0 & 2.8 & 0 \\
\hline \multirow[t]{7}{*}{3} & 1 & $89.9^{\mathrm{a}}$ & $10.5^{\mathrm{a}}$ & 5.4 & $3.5^{\mathrm{b}}$ \\
\hline & 2 & 52.6 & $8.8^{\mathrm{a}}$ & 4.9 & 1.5 \\
\hline & 4 & $74.2^{\mathrm{a}}$ & $7.0^{\mathrm{a}}$ & 6.5 & $3.5^{\mathrm{b}}$ \\
\hline & 8 & 29.4 & 4.8 & 4.3 & 0 \\
\hline & 15 & 28.7 & $5.9^{\mathrm{a}}$ & 2.8 & 1.5 \\
\hline & 30 & 34.6 & 4.3 & 2.8 & 0 \\
\hline & 60 & I & / & 1 & l \\
\hline \multirow[t]{7}{*}{4} & 1 & $71.7^{\mathrm{a}}$ & $7.9^{\mathrm{a}}$ & $7.3^{\mathrm{a}}$ & $5^{b}$ \\
\hline & 2 & $56.1^{a}$ & $7.9^{\mathrm{a}}$ & $6.8^{\mathrm{a}}$ & $5^{\mathrm{b}}$ \\
\hline & 4 & 1 & 1 & 1 & I \\
\hline & 8 & $67.5^{\mathrm{a}}$ & $5.9^{\mathrm{a}}$ & 6.0 & $3.5^{\mathrm{b}}$ \\
\hline & 15 & 38.2 & $6.0^{\mathrm{a}}$ & 6.3 & 1.5 \\
\hline & 30 & 32.5 & 5.3 & 4.4 & 0 \\
\hline & 60 & 46.8 & 4.7 & 5.2 & 0 \\
\hline \multirow[t]{7}{*}{5} & 1 & 26.3 & $9.5^{\mathrm{a}}$ & $7.7^{\mathrm{a}}$ & $3^{b}$ \\
\hline & 2 & 46.7 & $8.8^{\mathrm{a}}$ & 6.6 & 1.5 \\
\hline & 4 & 49.6 & $7.9^{\mathrm{a}}$ & 6.4 & 1.5 \\
\hline & 8 & 32.7 & $7.0^{\mathrm{a}}$ & 4.0 & 1.5 \\
\hline & 15 & 24.4 & $5.8^{\mathrm{a}}$ & 4.3 & 1.5 \\
\hline & 30 & 25.2 & 5.5 & 3.0 & 0 \\
\hline & 60 & 27.6 & 5.3 & 3.4 & 0 \\
\hline \multirow[t]{7}{*}{6} & 1 & $74.8^{\mathrm{a}}$ & $8.9^{\mathrm{a}}$ & $8.3^{\mathrm{a}}$ & $5^{\mathrm{b}}$ \\
\hline & 2 & $56.6^{\mathrm{a}}$ & $9.7^{\mathrm{a}}$ & $8.2^{\mathrm{a}}$ & $5^{b}$ \\
\hline & 4 & 46.2 & $7.1^{\mathrm{a}}$ & $8.1^{a}$ & $3^{\text {b }}$ \\
\hline & 8 & $67.0^{\mathrm{a}}$ & 5.6 & 5.2 & 2 \\
\hline & 15 & 36.6 & $6.9^{\mathrm{a}}$ & $6.8^{a}$ & $3^{b}$ \\
\hline & 30 & 28.7 & 5.4 & 5.3 & 0 \\
\hline & 60 & 44.3 & 5.3 & 6.0 & 0 \\
\hline \multirow[t]{7}{*}{7} & 1 & $96.1^{a}$ & $6.7^{\mathrm{a}}$ & $8.5^{\mathrm{a}}$ & $5^{\mathrm{b}}$ \\
\hline & 2 & $62.2^{\mathrm{a}}$ & $7.7^{\mathrm{a}}$ & $10.0^{\mathrm{a}}$ & $5^{\mathrm{b}}$ \\
\hline & 4 & 46.4 & $9.8^{\mathrm{a}}$ & $8.3^{\mathrm{a}}$ & $3^{\text {b }}$ \\
\hline & 8 & $62.9^{\mathrm{a}}$ & 5.3 & 5.9 & 2 \\
\hline & 15 & 39.1 & 3.9 & 4.3 & 0 \\
\hline & 30 & 34.1 & 5.5 & 5.6 & 0 \\
\hline & 60 & 41.0 & 4.6 & 3.9 & 0 \\
\hline \multirow[t]{7}{*}{8} & 1 & 1 & 1 & 1 & I \\
\hline & 2 & $59.6^{\mathrm{a}}$ & 3.0 & 3.2 & 2 \\
\hline & 4 & $46.1^{\mathrm{a}}$ & 2.7 & 3.7 & 2 \\
\hline & 8 & $56.6^{a}$ & 2.9 & 3.9 & 2 \\
\hline & 15 & 40.7 & 2.6 & 2.7 & 0 \\
\hline & 30 & $49.4^{\mathrm{a}}$ & 2.5 & 2.9 & 2 \\
\hline & 60 & 1 & 1 & 1 & I \\
\hline \multirow[t]{7}{*}{9} & 1 & 50.5 & 3.4 & 3.6 & 0 \\
\hline & 2 & 25.9 & 3.0 & 3.0 & 0 \\
\hline & 4 & $65.9^{\mathrm{a}}$ & 3.0 & 3.5 & 2 \\
\hline & 8 & 31.8 & 2.9 & 2.6 & 0 \\
\hline & 15 & 32.0 & 2.6 & 2.9 & 0 \\
\hline & 30 & 53.2 & 3.3 & 2.7 & 0 \\
\hline & 60 & 49.1 & 2.5 & 2.1 & 0 \\
\hline
\end{tabular}

${ }^{\text {aAbnormal values. }}$

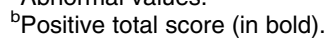

It has been reported that systemic oestrogen administration blocks hepatic IGF1 production and, consequently, suppresses connective tissue and bone metabolism (15). However, in the present study, all female athletes were normocycling and nobody was taking oral contraceptives, which make it unlikely that these factors may account for the resistance of the females to rhGH.

Based on a cut-off value for total score of $\geq 3$, the highest value of sensitivity of the detection approach was $66.6 \%$ at the 20th day of rhGH treatment. Comparing with the sensitivity of male subjects $(100 \%$ at the same time interval) (9), one can argue that combined detection of the three GH-dependent markers is unable to detect (satisfactorily) $\mathrm{GH}$ abuse in female athletes. Anyway, the dose of rhGH used in the present study was small for ethical reasons and is likely to be much lower than that which is commonly abused. In this context, anecdotal information suggests that many athletes are taking $\mathrm{GH}$ at a much higher dose than the one administered in this study (up to $16 \mathrm{IU} /$ day for several months) (16). Thus, the sensitivity of the test may well be greater in the doping population than it was found overall in our study group.

Detection of GH abuse in women would not be trickier than in men for another reason if women are GH resistant (14), female athletes will require higher doses of rhGH to obtain potential ergogenic benefits, thus making sensitivity of the test in a doping context similar in men and women.

In the present study (results not shown), we also verified whether the addition of the specific bone isoform of the alkaline phosphatase (b-ALP), a marker of bone formation (17), to the other markers would have improved the clinical predictivity of the test. However, sensitivity and specificity did not change by adding b-ALP in the detection approach, indicating that IGF1, ICTP and PIIINP are potentially capable to reach the full clinical predictivity of the test.

It appears that athletes who are abusing performance-enhancing agents are, in general, extremely well informed and aware of the most critical anti-doping controls. Thus, it is desirable that any doping test detects an illicit substance for some time after cessation of its administration. This can be partly overcome by out-of-competition testing but it is extremely difficult to perform in a fair and universal manner due to disparate access to athletes depending on their nationality and differing testing policies by the various sporting bodies (18).

The detection approach here-in proposed is optimized to pinpoint athletes who are actively taking rhGH, but could also be useful for detection of those who have stopped hormone intake some time previously. In fact, the sensitivity of the test after rhGH withdrawal is related not only to IGF1, which has a relatively short plasma half-life, but also to PIIINP and ICTP, endowed with a much longer half-life (19). 
As shown in the present study, in a GH-resistant population treated with low doses of rhGH, levels of PIIINP were in few subjects still abnormal after 30 days of rhGH withdrawal (Fig. 1). Although the sensitivity of $11.1 \%$ at 15 days after rhGH withdrawal is small, further studies are mandatory to establish whether it could be increased using different doses and times of rhGH administration.

Before closing, one major limitation of our work has to be outlined: though the number of control subjects used was not so small, validation of this detection approach will need a much higher number of athletes to avoid the occurrence of false positives, possibly with cut-off levels based on the intra-individual variability of GH-dependent markers (20). A blinded, placebocontrolled, randomized study should be performed.

In conclusion, this study reports the results of a new methodology for the detection of GH abuse in female athletes, based on levels of three GH-dependent markers, IGF1, PIIINP and ICTP. This detection approach has a high specificity in both genders (about $100 \%$ ), but a good sensitivity only in men (100 vs $66.6 \%$ in women after 3-week rhGH treatment). As female athletes supposedly use for doping purposes doses of rhGH higher than the ones we used, this detection tool maintains its validity.

\section{Declaration of interest}

We declare that there is no conflict of interest that could be perceived as prejudicing the impartiality of the research reported.

\section{Funding}

This research was supported by a grant of the Anti-Doping Commission (CVD) of the Italian Ministry of Health: 'Progetto di Ricerca Finalizzata 2005 - Estensione e validazione di una metodica per identificare la presenza di ormone della crescita esogeno'.

\section{Acknowledgements}

The authors acknowledge athletes, trainers, sport doctors and societies who participated enthusiastically to the present study; this project would not have been possible without their full collaboration.

\section{References}

1 Holt RI \& Sönksen PH. Growth hormone, IGF1 and insulin and their abuse in sport. British Journal of Pharmacology $2008 \mathbf{1 5 4}$ 542-556.

2 Gibney J, Healy ML \& Sönksen PH. The growth hormone/insulinlike growth factor-I axis in exercise and sport. Endocrine Reviews 200728 603-624.

3 Nelson AE \& Ho KK. A robust test for growth hormone doping present status and future prospects. Asian Journal of Andrology $200810416-425$.

4 Wu Z, Bidlingmaier M, Dall R \& Strasburger CJ. Detection of doping with human growth hormone. Lancet 1999353895.

5 Sonksen PH. Insulin, growth hormone and sport. Journal of Endocrinology $2001 \mathbf{1 7 0} 13-25$.

6 Dall R, Longobardi S, Ehrnborg C, Keay N, Rosén T, Jørgensen JO, Cuneo RC, Boroujerdi MA, Cittadini A, Napoli R, Christiansen JS,
Bengtsson BA, Sacca L, Baxter RC, Basset E \& Sönksen PH. The effect of four weeks of supraphysiological growth hormone administration on the insulin-like growth factor axis in women and men. GH-2000 Study Group. Journal of Clinical Endocrinology and Metabolism 200085 4193-4200.

7 Longobardi S, Keay N, Ehrnborg C, Cittadini A, Rosén T, Dall R, Boroujerdi MA, Bassett EE, Healy ML, Pentecost C, Wallace JD, Powrie J, Jørgensen JO \& Saccà L. Growth hormone (GH) effects on bone and collagen turnover in healthy adults and its potential as a marker of GH abuse in sports: a double blind, placebo-controlled study. The GH-2000 Study Group. Journal of Clinical Endocrinology and Metabolism 200085 1505-1512.

8 Wallace JD, Cuneo RC, Lundberg PA, Rosén T, Jørgensen JO, Longobardi S, Keay N, Sacca L, Christiansen JS, Bengtsson BA \& Sönksen PH. Responses of markers of bone and collagen turnover to exercise, growth hormone $(\mathrm{GH})$ administration, and $\mathrm{GH}$ withdrawal in trained adult males. Journal of Clinical Endocrinology and Metabolism 200085 124-133.

9 Sartorio A, Agosti F, Marazzi N, Maffiuletti NA, Cella SG, Rigamonti AE, Guidetti L, Di Luigi L \& Muller EE. Combined evaluation of resting IGF1, N-terminal propeptide of type III procollagen (PIIINP) and C-terminal cross-linked telopeptide of type I collagen (ICTP) levels might be useful for detecting inappropriate $\mathrm{GH}$ administration in athletes: a preliminary report. Clinical Endocrinology 200461 487-493.

10 Kniess A, Ziegler E, Kratzsch J, Thieme D \& Müller RK. Potential markers for the detection of hGH doping. Analytical and Bioanalytical Chemistry $20033 \mathbf{3 6}$ 696-700.

11 Erotokritou-Mulligan I, Bassett EE, Kniess A, Sönksen PH \& Holt RI. Validation of the growth hormone (GH)-dependent marker method of detecting $\mathrm{GH}$ abuse in sport through the use of independent data sets. Growth Hormone and IGF Research 2007 $17416-423$.

12 Powrie JK, Bassett EE, Rosen T, Jørgensen JO, Napoli R, Sacca L, Christiansen JS, Bengtsson BA, Sönksen PH \& GH-2000 Project Study Group. Detection of growth hormone abuse in sport. Growth Hormone and IGF Research 200717 220-226.

13 Nelson AE, Howe CJ, Nguyen TV, Leung KC, Trout GJ, Seibel MJ, Baxter RC, Handelsman DJ, Kazlauskas R \& Ho KK. Influence of demographic factors and sport type on growth hormone-responsive markers in elite athletes. Journal of Clinical Endocrinology and Metabolism 200691 4424-4432.

14 Burman P, Johansson AG, Siegbahn A, Vessby B \& Karlsson FA. Growth hormone (GH)-deficient men are more responsive to GH replacement therapy than women. Journal of Clinical Endocrinology and Metabolism 199782 550-555.

15 Ho KK \& Weissberger AJ. Impact of short-term estrogen administration on growth hormone secretion and action: distinct route-dependent effects on connective and bone tissue metabolism. Journal of Bone and Mineral Research 19927 821-827.

16 Jenkins PJ. Growth hormone and exercise. Clinical Endocrinology 199950 683-689.

17 Tobiume H, Kanzaki S, Hida S, Ono T, Moriwake T, Yamauchi S, Tanaka H \& Seino Y. Serum bone alkaline phosphatase isoenzyme levels in normal children and children with growth hormone (GH) deficiency: a potential marker for bone formation and response to GH therapy. Journal of Clinical Endocrinology and Metabolism 1997 82 2056-2061.

18 Ehrnborg C \& Rosén T. Physiological and pharmacological basis for the ergogenic effects of growth hormone in elite sports. Asian Journal of Andrology 200810 373-383.

19 Rigamonti AE, Cella SG, Marazzi N, Di Luigi L, Sartorio A \& Müller EE. Growth hormone abuse: methods of detection. Trends in Endocrinology and Metabolism 200516 160-166.

20 Sonksen PH. Insulin, growth hormone and sport. Journal of Endocrinology $2001 \mathbf{1 7 0} 13-25$.

Received 17 February 2009

Accepted 3 March 2009 